\title{
Monitoring of electrical current in rabbit and porcine cartilage tissue during electromechanical reshaping
}

\author{
Cyrus Manuel*, Allen Foulad, Dimitry Protsenko, Brian Wong \\ From 2nd Scientific Meeting of the Head and Neck Optical Diagnostics Society \\ San Francisco, CA, USA. 23-24 January 2010
}

Electro Mechanical Reshaping (EMR) with platinum needle electrodes has been recently developed to shape cartilage without conventional cut and suture surgery. This study investigates the relationship between the voltage applied, the electrical current measured during EMR with platinum needles, and the resulting shape. Monitoring the electrical current provides information to model the electro-chemistry, which will aid in determining the onset of shape stabilization. Rabbit septal, rabbit auricular, porcine auricular, and porcine costal grafts were bent into a $90^{\circ}$ angle using a moulage. Platinum needle electrodes were then placed in contact with the cartilage and a constant voltage was applied for a set time. The electrical current was measured during the process and total charge transferred was calculated. The cartilage specimen was then removed from the jig and photographed after one minute in order to determine the resulting bend angle.

Results show that a higher current in tissue is produced with increasing applied voltage. Each current trace is unique and is dependent on tissue thickness and inter-electrode distances. Understanding the electrical current process ultimately leads to optimizing EMR and feedback control. Voltage, for example, could be varied in real-time during EMR to produce a constant chemical reaction rate and potentially reduce total tissue dehydration in contact with electrodes.

In conclusion, electric current traces provide information about chemical kinetics during EMR that depend on exposure settings, and monitoring these traces is an important step in optimizing the reshaping process.
Published: 29 October 2010

doi:10.1186/1758-3284-2-S1-021

Cite this article as: Manuel et al:: Monitoring of electrical current in

rabbit and porcine cartilage tissue during electromechanical reshaping.

Head \& Neck Oncology 2010 2(Suppl 1):O21.
Submit your next manuscript to BioMed Central and take full advantage of:

- Convenient online submission

- Thorough peer review

- No space constraints or color figure charges

- Immediate publication on acceptance

- Inclusion in PubMed, CAS, Scopus and Google Scholar

- Research which is freely available for redistribution

Submit your manuscript at www.biomedcentral.com/submit
C Biomed Central 